\title{
Development of Management Industry of Lawang Oil (Cinnamomum Culilawan Blume) in Ujung Kia Village, Ki District, Boven Digoel Regency, Papua Province
}

\section{Sebestina Siman ${ }^{1 *}$, Hendricus Lembang ${ }^{2}$}

1,2 Departement of Economics, Musamus University, Merauke

\section{A R T I C L E I N F O}

Article history:

Received 19 February 2019

Received in revised form

16 March 2019

Accepted 15 April 2019

Available online 26 May 2019

\section{Keywords:}

commodities, lawang oil, industrial centers, feasible, welfare.

\section{A B S T R A C T}

Lawang oil (cinnamomum culilawan $\mathrm{BL}$ ) is a commodity from non-timber forest products from Ujungkia Village, Ki District, Boven Digoel Regency. The rich of natural resources can be processed into a commodity to increase local community welfare and local revenue (PAD). So that this study aims to determine the feasibility of developing management industry of lawang oil in Ujungkia Village which will become an industrial center and a new center for economic growth. The type of research used is descriptive qualitative, combined with quantitative research, namely the method of analysis of Loss / Profit Ratio and SWOT. The results of the research are the development of management industry of the lawang oil in Ujungkia Village, Ki District, Boven Digoel Regency which has good and feasible prospects to be realized based on the results of the R/C analysis and SWOT analysis. Based on the $R / C$ ratio analysis that is obtained is equal to 1.585 which means the value of $R / C$ ratio $\geq 1$, in this case management industry of Lawang oil activities are profitable. Then the results of the SWOT analysis obtained Total Strength - Total Weakness (S-W) which is 1.86 or $X=1.86$. While the difference in Total Opportunities - Total Threats $(0-T)$ is 1.44 or $Y=1.44$. This means that $(1.86 ; 1.44)$ is in Quadrant I (positive, positive).

\footnotetext{
* Corresponding author.

E-mail addresses: sebestinasiman@unmus.ac.id (Sebestina Siman)
} 


\section{Introduction}

Boven Digoel Regency is one of the regencies in the Papua Province which has a tropical forest area of 2,303,300.63 Ha. (Boven Digoel Regency Forestry Service 2014 cf. http: //www.opd.boven digoelkab.go.id). So that Boven Digoel Regency has a rich of forest products such as: logs, sawn wood, plywood and films faced and also non-timber forest products. Especially for a lot of non-timber forest product includes various types of vegetation such as lawang wood, masogi wood and Buah Merah Tree, Agarwood and so on. About 45 types of essential oil-producing plants grow in Indonesia, 15 of which have become export commodities, one example of which is lawang oil (Ma'mun, 2006; Purwowatiningrum R.S., et al., 2013). The processed products of these plants have economic value as commodities to be traded. Especially for lawang wood can be processed to produce Lawang oil. Lawang oil (cinnamomum culilawan $\mathrm{BL}$ ) is classified as essential oil. Essential oil is one of Indonesia's natural products that is widely used as a basic ingredient in medicine, perfume, as a flavor and preservative of food, aromatherapy (Ma'mun, 2014).

The main content of lawang oil is eugenol (69\%) and safrol (21\%) (Sastrohamidjojo, 2005) while the results of testing with GC-MS contain eugenol 67.35\% (Kapelle, Tun Tedja Irawadi et al., 2016). The content of eugenol compounds in lawang oil from Ujungkia Village is $75.34 \%$ based on the results of laboratory tests at the Makassar Polytechnic State University. The quality of lawang oil from Ujungkia Village is much better because it has a high level of purity. So that lawang oil has the potential as a competitive commodity if it is managed efficiently, economically and sustainably. As agro-industry is an activity that utilizes the results of the primary sector (agriculture, plantation and forestry) as raw material, designing and providing equipment and services for these activities into the agro-industry sector. (Austin, J.E, 1981; Ghiffari, Rizki Adriadi and Eko Budi Santoso, 2015). This sector will be able to contribute to regional development and the community as a source of income for the community and can increase Lokal Original Income (PAD). The development of the industrial sector in the regions is a key sector of economic growth, (Tambunan, 2006).

In accordance with the era of decentralization and regional autonomy with special autonomy for regions in the Papua Province based on the Special Autonomy Law Number 21, 2001 concerning the special autonomy of the Papua Province and Law Number 32, 2004 concerning the authority of the regional government and Law Number 33, 2004 about the financial balance of the regional government. The mandate of these laws and regulations clearly and explicitly gives broader authority to local governments to manage and develop their regions in order to build independence and reduce fiscal dependence. Therefore, the regional government strives to explore the potential sources of regional revenue that are legal according to legal regulations and laws.

Strategies carried out by local governments with accelerated development in all fields to create prosperity and justice for the community. The regional government of Boven Digoel Regency took steps in development policy by keeping oriented towards pro growth, pro poors and pro jobs. So that the steps taken by the regional government are to run a very strategic field, specially the economy and trade. The populist economy is a priority because it can touch the wider community and especially the indigenous Papuans.

One of the economic sectors that is the concern of the Regional Government is to explore the potential of the region, namely to revive business opportunities in the management industry of lawang oil. Because so far, the efforts of local communities in Lawang Oil management activities have not been the main source of livelihood because they are still a side business. This activity has not been able to provide hope as the main source to support their families. Such as distillation of lawang oil in Ujungkia Village that has been carried out since the 1990s. Even people from the Saki Clan have used distillation technology through government assistance. However, refining and distillation operations have not been operational since the beginning of 2000 .

Distillation management activities in the area are no longer operating because of several constraints. The main constraints are: it is very difficult to access the market for their products, the costs of production and management are still expensive because they are still managed in a simple, small scale, limited funding from financial institutions, low quality human resources, lack of innovation and unsustainable counseling from the government, and the impact of situation of monetery crisis as well as nastional political stability in 1997-1998. So at that time, the management of lawang oil was felt to be more difficult and did not provide hope to continue. Moreover, the attention of the local government at that time was gone. As a result, the people who work in lawang oil processing began to switch to other jobs that were considered more prospects to meet their household needs.

By looking at the real conditions, the potential of the area and the constraints faced, the Regional Government again paid attention to empowering the people in Ujungkia Village because in this area there was a large amount of raw materials available and easily as well as the availability of labor from the local 
community. Local governments are trying to encourage development by facilitating local communities to be involved in accelerating development in order to increase economic capacity and welfare through increasing their income. The development of managemen industry of lawang oil in Ujungkia Village, Ki District, Boven Digoel Regency, Papua Province can be an industrial center and a new center for economic growth.

Furthermore, in this study can be illustrated the study flow of the development prospects of management business of lawang oil using an analytical method that can provide an overview of the conclusions and recommendations for the stakeholders. The flow of the conceptual framework as shown in the figure 1 below:

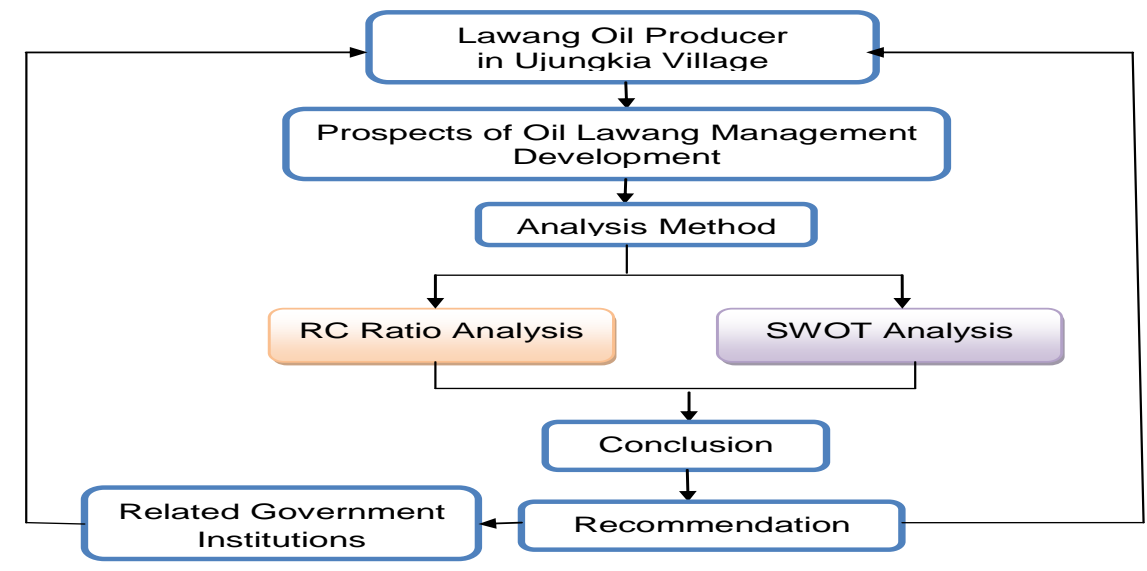

Figure 1. Study Flow

\section{Methods}

The type of research used is descriptive qualitative and quantitative research by combining Loss / Profit Ratio and SWOT analysis. The research activities were conducted in Ujungkia Village, Ki District, Boven Digoel Regency. The choice of location is based on the consideration that this area is one of the regions that has sufficient available lawang wood resources.

\section{Result and Discussion}

\section{R/C Ratio Analysis}

$\mathrm{R} / \mathrm{C}$ ratio analysis was used to determine the management of lawang oil distillation activities that were developed to provide benefits by calculating the $\mathrm{R} / \mathrm{C}$ ratio. The formula is as follows:

$\mathrm{R} / \mathrm{C}$ ratio : $\mathrm{TR} / \mathrm{TC}$

$\pi=\mathrm{TR}-\mathrm{RC}$

Explanation:

$\mathrm{TR}=$ Total revenue is production multiplied by the selling price $(\mathrm{Rp})$

$\mathrm{TC}=$ Total cost is the total production cost $(\mathrm{Rp})$

$\pi=$ Profit

\section{Decision Criteria:}

1. If the value of $\mathrm{R} / \mathrm{C}$ ratio $\geq 1$, it means profitable

2. If the value of $\mathrm{R} / \mathrm{C}$ ratio $<1$, it means loss

Lawang oil price obtained from processing refining is $780.5 \mathrm{ml}$, then packaged into 1 small bottle. Each bottle contain $30 \mathrm{ml}$ with price of Rp. 50,000, - per bottle. The number of bottles that can be produced is as many as 26 bottles so that calculations can be obtained, namely:

1. Total revenue which is $\mathrm{Rp} .1,300,000$, - which is produced from $50.7 \mathrm{~kg}$ dry lawang tree bark. (before being dried / wet lawang tree bark $84.6 \mathrm{~kg}$ ).

2. The total cost reduced is Rp. 820,000 , which consists of variable costs, including:

1. Labors consist of 2 people who take material in the forest for 1 day with the amount of Rp.240,000, - Assumed one working day per one labor = Rp. 120,000, -

2. Transportation cost of raw materials $=$ Rp. $250.000,-$ 
3. Cost of Lawang bark cutting into small pieces for one person for $1 \frac{1}{2}$ days is Rp.180,000,-

4. Biaya penjemuran 1 orang dengan waktu kerja efektif selama selama 2 hari yaitu setara dengan $1 / 2$ hari atau sebesar Rp. $60.000,-$.

5. The drying cost of 1 person with an effective working time of 2 days is equivalent to $1 / 2$ day or Rp. 60,000 .

6. Labor distillation wages for 2 people for 1 day amounting to Rp. 240,000, -

7. Cost of firewood material is $\mathrm{Rp}$. 50.000,-

8. Cost of water is Rp. 30.000,-

9. Cost of small bottle packaging is @ Rp. 5.000,- with amount 26 bottle = Rp.130.000,-

10. Cost of tools maintenance are assumed to be Rp. 20,000 per one time distillation.

11. Other variable costs are Rp. 100.000,-

So that it obtained R/C ratio : TR $/ \mathrm{TC}=1.300 .000 / 820.000=1,585$. Based on the criteria using the $\mathrm{R} / \mathrm{C}$ ratio, that is obtained is equal to 1.585 which means the value of $\mathrm{R} / \mathrm{C}$ ratio $\geq 1$, in this case lawang oil management activities are profitable. So that the decision to develop Lawang Oil is "feasible" to be considered as an agro-industrial business. Futhermore, there are also greater benefits, namely opening employment opportunities for workers directly involved in this industry. With the increase in community welfare, it will create a multiplier effect for the economy in this area.

\section{SWOT Analysis}

The study of the objective conditions for developing the central oil lawang industry management in Kampung Ujungkia, Ki District, Boven Digoel Regency can be analyzed by using the SWOT analysis approach (strengths, weaknesses, opportunities, threats), which includes internal variables such as Human Resources (HR), process, product, price, place and distribution channel, promotion and customer service. While external variables such as: economic, social, cultural, political and market. The following are variables and internal factor dimensions in table 1 below:

Table 1. Variable and Dimension of Internal Factors of SWOT

\begin{tabular}{|c|c|c|}
\hline NO. & VARIABLES & DIMENSIONS \\
\hline \multirow[t]{6}{*}{1.} & Human Resources (HR) & a. $\quad$ Total labors \\
\hline & & b. Educational level \\
\hline & & c. Availibility of experts/consultant \\
\hline & & d. Training \\
\hline & & $\begin{array}{l}\text { e. Internal coordination in home industry } \\
\text { organizations. }\end{array}$ \\
\hline & & f. Incentives, bonuses awards. \\
\hline \multirow[t]{4}{*}{2.} & Process & a. Industrial growth \\
\hline & & b. Development program \\
\hline & & $\begin{array}{l}\text { c. Effectiveness and efficiency of work } \\
\text { procesess }\end{array}$ \\
\hline & & d. Accessibilities and facilities \\
\hline \multirow[t]{4}{*}{3.} & Product (goods) & a. Quality of product \\
\hline & & b. Quality of lawang bark material \\
\hline & & c. Product brand \\
\hline & & d. Product packaging \\
\hline \multirow[t]{4}{*}{4.} & Prices & a. Operating costs \\
\hline & & b. Raw materail cost \\
\hline & & c. Product tax \\
\hline & & d. Finished product prices \\
\hline \multirow[t]{2}{*}{5.} & Location or distribution channel & a. Location of company operational. \\
\hline & & b. Broad coverage area of distribution \\
\hline \multirow{3}{*}{6.} & Promotion & a. Advertise and promotion costs \\
\hline & & b. Sponsorship \\
\hline & & c. Internet media \\
\hline 7. & Costemer service & a. Settlement of problems or compaints \\
\hline & & b. Services. \\
\hline
\end{tabular}


Meanwhile, external factors greatly determine the success or failure of business, the following external environment variables can be identified as in table 2 below:

Table 2. Variable and Dimension of External Factors of SWOT

\begin{tabular}{|c|c|c|}
\hline NO. & VARIABLES & DIMENSIONS \\
\hline 1. & Ekonomy & $\begin{array}{l}\text { a. Inflation rate } \\
\text { b. Income per capita } \\
\text { c. Tax value set by the government. }\end{array}$ \\
\hline 2. & Social & $\begin{array}{l}\text { a. Pro and contra of community towards the existence of lawang oil } \\
\text { refining factory. } \\
\text { b. Impact of waste on the community environment. }\end{array}$ \\
\hline 3. & Culture & $\begin{array}{l}\text { a. Culture of people who always want to use lawang oil. } \\
\text { b. Spirit of cooperation toghter but without a productivity target. }\end{array}$ \\
\hline 4. & Politics & $\begin{array}{l}\text { a. Government commitment and policy regarding the support of } \\
\text { lawang oil management facilities. } \\
\text { b. Ease of regulation such as license. }\end{array}$ \\
\hline 5. & Market & $\begin{array}{l}\text { a. Competition with other similar business industries } \\
\text { b. Threatment of newcomers } \\
\text { c. Treatment of subtitute products }\end{array}$ \\
\hline
\end{tabular}

Internal Environment

1) Strengths (S)
a. Source of lawang bark are available in large quantities
b. A large number of workers are available
c. An high community interest in developing lawang oil management industry.
d. There was experience of lawang oil processing in Ujungkia Village in decade of the 1990s.
e. Membership of small and medium industries and households is voluntary, opened and democratic.
f. Production costs are relatively low and cheap
g. The price of pure lawang oil product is copetitve with the price for one bottle Rp. 50.000,- which has been packaged in $30 \mathrm{ml}$ size bottle. It is relatively safe, neat and attractive.
h. Lawang oil products have a level of genuineness with eugenol 75,34\%

2) Weaknesses (W)

a This business is just starting up again

b Weak capital structure

c Low quality of human resources (low educational level)

d Inovation, creatity and using the new work methods are low.

e Spirit of cooperation witk working together without specialization and professional ability.

$\mathrm{f}$ The use of tools that have not been effective such as chopping knife, old motorcyle and other manual tools.

g Community mindset dose not have much business-oriented to pursue profits.

h There are no regular customers.

i There are no cooperative instituions or viilage-owned enterprises or other instituions to be distributors.

j The distance from the location of lawang oil processing to the district capital is quite far.

External Environment

1) Opportunities (O)

a Commitment and goodwill of Boven Digeol Regent to built a prime product industrial center specially lawang oil management indstry in Ujungkia Village.

b National policies by central and local government (regent) that support management industrial center.

c This product is a regency icon as a typical product from Boven Digoel regency.

d Support form Department of industry and Commerce which os a program to provide lawang oil refining facilities and building. 
e There are quite potential market opportunites in the capital of Boven Digoel Regency, Merauke City and Jayapura City.

f People's purchasing power is increasing every year along with the increase of income per capita.

$\mathrm{g}$ There is a tendency of people who prefer to use tradional herbal medicines.

$\mathrm{h}$ There is no competitor of lawang oil producer in the southern part of Papua.

i Lawang oil product that are from other parts of Papua have been known as genuine products.

2) Threats (T)

a Advanced technology and increasingly developed work methods that have not yet been mastered.

b The need for innovation and creativity to meet the needs of customers..

c Regulations and policys that often change every succession of regional government leadership.

d The threat of using other subtitute products (such as eucalyptus oil, masogi oil, sandalwood oil etc.)

Based on the identification of variables, dimensions and indicators so that parameters are set according to the objective conditions of the internal and external environmental conditions of lawang oil management business plan. Therefore weights on each factor are made according to the importance of the influence of these factors, namely weighting is assessed from:

Number $0,0=$ not important

Number 1 = very important

Because giving this weight is intended to have an impact on strategic factors. While giving a rating from value 1 to value 9 for each variable. A value of 1 means that it is very unrelated until the value of 9 which means it is very related. As for weighting, the average percentage of the corresponding indicators has one value for the overall number of indicators in one variable, then the variables will be given the following assessment:
LOW
if the value is between $0-3$
MEDIUM : $\quad$ if the value is between 3,1-6
HIGH : if the value is between 6,1-9

Strenght posture is a cumulative calculation of value of the internal factor variable, namely $\mathrm{S}+(-$ $\mathrm{W}$ ) as in the table 3 below:

Table 3. S-W Analysis Calculation

\begin{tabular}{|c|c|c|c|c|}
\hline No. & STRENGHT & Weight & Rating & Scores \\
\hline 1 & 2 & 3 & 4 & $5(4 X 5)$ \\
\hline 1 & Many raw materials are available & 0,32 & 9 & 2,88 \\
\hline 2. & The number of workers are available a lot & 0,07 & 5 & 0,35 \\
\hline 3. & $\begin{array}{l}\text { Spirit of local community in developing this lawang oil } \\
\text { management business has increased }\end{array}$ & 0,04 & 6 & 0,24 \\
\hline 4. & There was experience of lawang oil refining in decade of 1990s. & 0,07 & 5 & 0,35 \\
\hline 5. & Membership is voluntary, opened and democratic & 0,09 & 7 & 0,63 \\
\hline 6. & Mutual trust in society as social capital. & 0,12 & 8 & 0,96 \\
\hline 7. & Production costs are relatively low & 0,35 & 3 & 0,11 \\
\hline 8. & Product prices are quite competitive & 0,075 & 7 & 0,53 \\
\hline \multirow[t]{3}{*}{9.} & Genuine guaranteed & 0,18 & 8 & 1,44 \\
\hline & Total Strength & 1 & & 7,48 \\
\hline & WEAKNESS & Weight & Rating & Scores \\
\hline 1. & This new business will star up again & 0,11 & 6 & 0,66 \\
\hline 2. & Weak capital structure & 0,05 & 8 & 0,40 \\
\hline 3. & Low qualty of human recources & 0,17 & 6 & 1,02 \\
\hline 4. & Lack of innovation and creativity & 0,12 & 5 & 0,60 \\
\hline 5. & Lack of specialization and profesionalism & 0,13 & 3 & 0,39 \\
\hline 6. & $\begin{array}{l}\text { The use of tools for processing raw materials has not been } \\
\text { effective, such as chopping knife and old motorcycles }\end{array}$ & 0,07 & 6 & 0,42 \\
\hline 7 & $\begin{array}{l}\text { The community mindset has not been business oriented which } \\
\text { applies the principles of efficiency, effectiveness and economics. }\end{array}$ & 0,09 & 8 & 0,72 \\
\hline 8. & There are no regular customer & 0,05 & 3 & 0,15 \\
\hline 9 & $\begin{array}{l}\text { There are no economic institutions (cooperatives / Village-Owned } \\
\text { Enterprises) for product distribution and marketing }\end{array}$ & 0,14 & 6 & 0,84 \\
\hline 10 & The distance from the production location to the city center of the & 0,07 & 6 & 0,42 \\
\hline
\end{tabular}


regency is relatively far

Total Weakness

Diffrence of Total Strengths - Weaknesses $(S-W=1,86)$

Competitive posture is a cumulative calculation of the value of the external factor variable, $0+$ $(-\mathrm{T})$ as shown in the table below:

Table 4. 0-T Analysis Calculation

\begin{tabular}{|c|c|c|c|c|}
\hline NO. & OPPORTUNITY & Weight & Rating & Scores \\
\hline 1. & $\begin{array}{l}\text { Commitment and goodwill from the local } \\
\text { government (regent) to build potential industrial } \\
\text { centers. }\end{array}$ & 0,23 & 9 & 2,07 \\
\hline 2. & $\begin{array}{l}\text { National policies by the central and local } \\
\text { government to support management industrial } \\
\text { centers }\end{array}$ & 0,17 & 7 & 1,19 \\
\hline 3. & $\begin{array}{l}\text { This product is a regency icon as a typical product } \\
\text { from Boven Digoel regency }\end{array}$ & 0,05 & 7 & 0,35 \\
\hline 4. & $\begin{array}{l}\text { Support form Department of industry and Commerce } \\
\text { which as a program to provide lawang oil refining } \\
\text { facilities and building. }\end{array}$ & 0,18 & 8 & 1,44 \\
\hline 5. & $\begin{array}{l}\text { There are quite potential market opportunites in the } \\
\text { capital of Boven Digoel Regency, Merauke City and } \\
\text { Jayapura City. }\end{array}$ & 0,16 & 7 & 1,12 \\
\hline 6. & $\begin{array}{l}\text { People's purchasing power is increasing every year } \\
\text { along with the increase of income per capita. }\end{array}$ & 0,04 & 5 & 0,2 \\
\hline 7. & $\begin{array}{l}\text { There is a tendency of people who prefer to use } \\
\text { tradional herbal medicines. }\end{array}$ & 0,07 & 7 & 0,49 \\
\hline 8. & $\begin{array}{l}\text { There is no competitor of lawang oil producer in the } \\
\text { southern part of Papua. }\end{array}$ & 0,06 & 4 & 0,24 \\
\hline \multirow[t]{3}{*}{9.} & $\begin{array}{l}\text { Lawang oil product that are from other parts of } \\
\text { Papua have been known as genuine products. }\end{array}$ & 0,04 & 5 & 20 \\
\hline & Total Opportunities & 1 & & 7,30 \\
\hline & THREATMENT & Weight & Rating & Scores \\
\hline 1 & $\begin{array}{l}\text { Advanced technology and increasingly developed } \\
\text { work methods that have not yet been mastered. }\end{array}$ & 0,22 & 7 & 1,54 \\
\hline 2. & $\begin{array}{l}\text { The need for innovation and creativity to meet the } \\
\text { needs of customers. }\end{array}$ & 0,33 & 5 & 1,65 \\
\hline 3. & $\begin{array}{l}\text { Regulations and policys that often change every } \\
\text { succession of regional government leadership }\end{array}$ & 0,29 & 7 & 2,03 \\
\hline \multirow[t]{2}{*}{4.} & $\begin{array}{l}\text { The threat of using other subtitute products (such as } \\
\text { eucalyptus oil, masogi oil, sandalwood oil etc.) }\end{array}$ & 0,16 & 4 & 0,64 \\
\hline & Total Threatments & 1 & & 5,86 \\
\hline
\end{tabular}

Difference of Total Oppotunities - Threatments (O-T = 1,44)

Based on both Table 3 and Table 4, the difference between Total Strength - Total Weakness $=\mathrm{S}-\mathrm{W}$ $=1.86$ or $\mathrm{X}=1.86$. While the difference in Total Opportunities - Total Threats $=0-\mathrm{T}=1.44$ or $\mathrm{Y}=1.44$. which means $(1.86 ; 1.44)$ is in Quadrant I (positive, positive). It is showned in Figure 2 below. It indicates that a lawang oil management industry is strong and has a chance. The strategy recommendation is progressive which is very possible to continue to be developed and achieve maximum progress. 


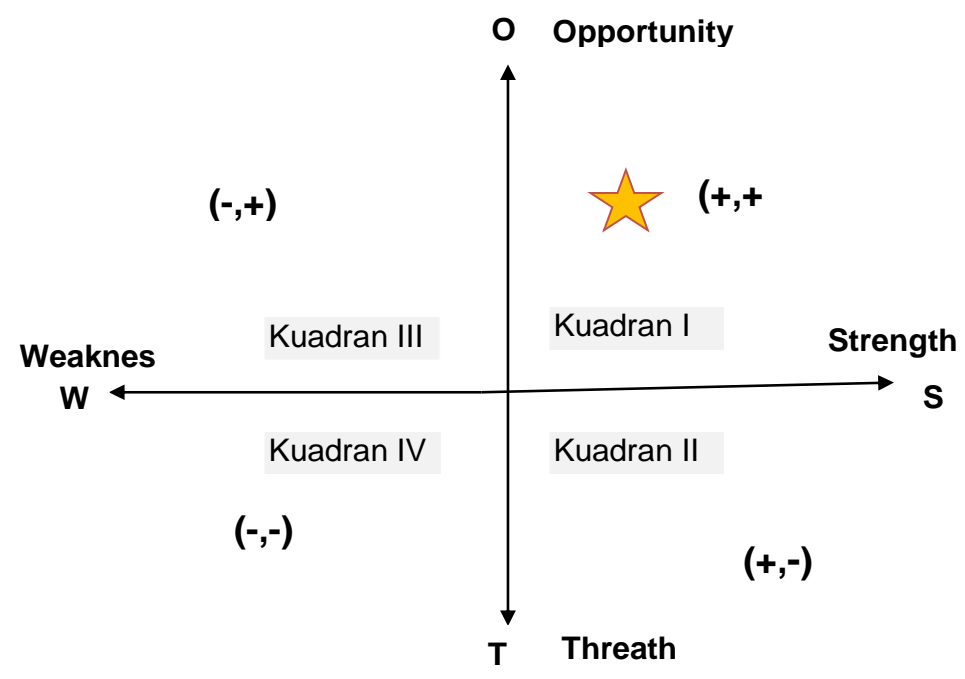

Figure 2. SWOT Quadrant

Based on the analysis of the internal and external environment as described above, the strategies needed are as follows:

Strategies (ST):

a. Increasing the labor capacity through education, training, coaching and counseling to be able to adapt and be able to use new methods and technologies that can be used in the workplace to support the production of lawang oil processing.

b. Improve skills and creative abilities that can adapt to customer needs and demands.

c. Building a sense of belonging to develop the management industry by maintaining the cohesiveness of members, rewards and establishes partnerships, especially the local government and private companies.

d. Improve product quality and quantity by setting competitive prices.

Strategies (SO):

a. Manage raw material sources wisely to support sustainable development.

b. Increasing the absorption of labor to be involved in the industrial sector of lawang oil management while remaining oriented towards principles of busness economy.

c. Maintaining product quality especially authenticity with eugenol content which ranges from $75.34 \%$.

d. Maintaining and continuing to stimulate the local community interest in the lawang oil management which can be a source of increased income for the community, village and regency.

e. Strenghtening partnerships with local governments in this case the Department of Industry and Commerce to provide assistance and guidance so that this business continues to grow up.

f. Increasing promotion through sponsorships and the introduction of these products directly so that they can be better known, especially the benefits for prospective consumers.

Strategies (WT) :

a. Improve capital structure through cooperation and partnerships such as government and private companies.

b. Increasing skills and professionalism of lawang oil labors who are able to use new methods and technologies.

c. Provide an opportunity to learn to innovate and be creative so that it can help simplify work methods and product smarketing.

d. Developing a productive work sprit and clear division of tasks through work specialization.

e. Using supporting tools that can save work time, reduce production and operational costs in order to increase production.

f. Developing partherships with financial institutions, economic institutions that can function as distributors and marketing. 
Strategies (WO):

1. The commitment of the regency government in building prime industrial centers, namely the lawang oil management in Ujungkia village.

2. Supporting the policies of the regency government of Boven Digoel Regency to make lawang oil products as a regional specialty product.

3. Willingness to become a villageof lawang oil management industry fostered by the Department of Industry and Commerce.

4. Increase promotion to the potential regions of product marketing such as in capital city of Boven Digoel Regency, Merauke City and also Jayapura City.

5. Open the opportunity to partner with various parties.

\section{Marketing Prospects}

Development for the lawang oil management indsutry as one of the non-timber forest product commodities has considerable potential. The needs as part of demand side of lawang oil considering the benefits especially for health are quite high. The use of traditional medicine by the community seems to remain widespread and continues to increase. This is caused by several factors including: 1) The level of public health who need treatment, 2) Market segments that prefer traditional or herbal medicines, 3) The tendency of visitors buy a commodity that has a typical product as a souvenir.

Potential market segments of lawang oil commodities from Ujungkia Village are directed to areas such as Tanah Merah Town, Jayapura City and Makassar City. So that this commodity has economic benefits that can provide profit opportunities and increase family income. More than that, it will also provide social benefits, namely opening employment opportunities, reducing unemployment, reducing poverty and spuring the economy in the region as well as improving people's living standards around lawang oil management industry. Therefore, the development potential of lawang oil 1 through the development program of production center in Ujungkia Village has a bright prospect. The existence of production center, small-scale industries of households and medium-sized industries will emerge as one of the locomotives of regional economic growth as well as induced sectors.

\section{Conclusion}

The efforts to develop and manage an lawang oil processing industry in Ujungkia Village, Ki District, Boven Digoel Regency have feasible and bright prospects to be realized both based on the results of R/C analysis and SWOT analysis.

Based on the R/C ratio analysis that is obtained is equal to 1.585 which means the value of $\mathrm{R} / \mathrm{C}$ ratio $\geq 1$, in this case management industry of Lawang oil activities are profitable. Then the results of the SWOT analysis obtained Total Strength - Total Weakness (S-W) which is 1.86 or $\mathrm{X}=1.86$. While the difference in Total Opportunities - Total Threats $(0-\mathrm{T})$ is 1.44 or $Y=1.44$. This means that $(1.86 ; 1.44)$ is in Quadrant I (positive, positive). In this case, it indicates that a business is strong and has a chance. The strategy recommendation is progressive which is very possible to continue to be developed and achieve maximum progress.

So that, this commodity has economic benefits that can provide profit opportunities and increase family income. More than that, it will also provide social benefits, namely opening employment opportunities, reducing unemployment, reducing poverty and spuring the economy in the region as well as improving people's living standards around lawang oil management industry.

\section{Reference}

Ghiffari, Rizki Adriadi dan Eko Budi Santoso, 2015. Penentuan Cluster Pengembangan Agroindustri Pengolahan Minyak Kayu Putih di Kabupaten Buru, Jurnal Teknik ITS Vol. 4, No. 2, (2015) ISSN: 2337-3539 (2301-9271 Print), Jurusan Perencanaan Wilayah dan Kota, Fakultas Teknik Sipil dan Perencanaan, Institut Teknologi Sepuluh Nopember (ITS).

Kapelle, Tun Tedja Irawadi; Meika Syahbana Rusli, Djumali Mangunwidjaja, Zainal Alim Mas'ud, 2016. Rekayasa Proses Sintesis Piperonal dari Kulit Lawang (Cinnamomum culilawan Blume) sebagai Prekursor Obat Kanker, Jurnal Penelitian Hasil Hutan Vol 34 No. 3, September 2016, ISSN:02164329. 
Ma'mun, 2014. Sirkuler Informasi Teknologi Tanaman Rempah dan Obat - Petunjuk Teknis Penanganan Bahan dan Penyulingan Minyak Asitiri, ISBN 978-979-548-043-3. , Undang-Undang Otonomi Khusus no. 21 tahun 2001 tentang Otonomi khusus Provinsi Papua. Undang-Undang No. 32 tahun 2004 tentang kewenangan pemerintah daerah. No. 33 tahun 2004 tentang perimbangan keuangan pemerintah daerah.

Purwowatiningrum R.S., Ngadiwiyana, Nor Basid AP., 2013. Sintesis 3,4-Metilendioksibenzaldehid dari Safrol pada Minyak Lawang (Cinnamomum Cullilawan, BL) sebagai Senyawa Antibakteri, Jurnal Sains dan Matematika, Vol.21. (4):92-97. Universitas Diponegoro, Semarang.

Sastrohamidjojo, H., 2005. "Prospek Minyak Atsiri Indonesia". Makalah. Disampaikan pada Seminar Nasional Peningkatan Produktivitas Hutan. Fakultas Kehutanan UGM, 26-27 Mei 2005. Proyek ITTO. (Personal Comm.)

Tambunan, T. (2006). Upaya-upaya meningkatkan daya saing daerah. Makalah Seminar. Pasca sarjana Universitas Sriwijaya. 